\title{
DIE-OFF OF UTAH JUNIPER NATURAL BRIDGES NATIONAL MONUMENT
}

\author{
DARRELL WEBER $\downarrow$ DEPARTMENT OF BOTANY AND RANGE SCIENCE \\ BRIGHAM YOUNG UNIVERSITY $\bullet$ PROVO
}

DAVID NELSON $\bullet$ USDA FOREST SERVICE

SHRUB SCIENCE LABORATORIES $\bullet$ PROVO

\section{$\bullet \quad$ INTRODUCTION}

Utah junipers (Juniperus osterosperma (Torr.)) are the dominant trees in the landscape of the southwestern states (35 million hectares). In Utah, the pinyon-juniper woodland represents $28.6 \%$ of the vegetation and are an important part of the aesthetic value of the Utah national parks. Over the past several years, extensive foliar damage has occurred to Utah juniper, yet little foliar damage has been observed in Natural Bridges National Monument, Canyonlands National Park, Arches National Park, Mesa Verde National Park and Colorado National Monument. The characteristic pattern is for the distal foliage to become chlorotic and die. Mortality progresses along twigs until whole branches or even the entire tree dies. The cause for the foliar damage is unknown. The loss of juniper trees in the national parks in southern Utah would have a dramatic ecological impact and would be an aesthetic blight in the parks. The purpose of this investigation is to determine the cause of the die-off of Utah junipers and suggest management options concerning the juniper die-off problem.

\section{$\checkmark \quad$ STUdY AREAS}

The Natural Bridges area was made a national monument in 1908 and covers about 26 square kilometers of area. Seven transects of juniper trees were established in the Natural Bridges National
Monument in 1991 to follow the changes in the dieoff problem over time. These transects were evaluated in 1992 to see what changes in die-off may have occurred in the past year. Prior to 1991 the study area had been in a drought for several years. During the end of 1991 and during 1992 the rainfall was above normal. If drought stress was part of the die-off problem, then there should be a decrease in the level of juniper die-off.

A second study area was selected in the Canyonlands National Park (Needles area) for comparison to the Natural Bridges area. Six transects were established in the needles study area and the junipers evaluated for disease problems.

\section{$\checkmark \quad$ BASIC APPROACH}

The basic approach to determining the cause of Utah juniper die-off is to consider possible causes and then obtain evidence for or against the hypothesis. After the cause of juniper die-off has been determined, then management options will be evaluated.

1. DETERMINING THE EXTENT OF THE UTAH JUNIPER DIE-OFF PROBLEM IN NATURAL BRIDGES NATIONAL MONUMENT AND IN THE NEEDLES AREA OF CANYONLANDS NATIONAL PARK. 
The seven reference transects previously established in Natural Bridges National Monument were evaluated again to determine if any changes in the extent of juniper die-off had occurred in the past year with the increased moisture. Six new transects were established in the Needles area of Canyonlands National Park in different environmental conditions such as ridges, washes, flood plains, etc. At each transect, 40 Utah juniper trees were selected by the quarter method (Phillips 1959). Each tree was measured for height, trunk diameter, signs and symptoms of diseases, insect damage, nonparasitic injury, die-off symptoms, vigor and percent of decadence. Soil and plant tissue samples were collected and analyzed for elements.

Nitrogen was determined by the Kjeldahl procedure using sulfuric acid digestion and the concentrations of the following minerals: $\mathrm{K}, \mathrm{Ca}, \mathrm{Mg}$, $\mathrm{Na}$, and $\mathrm{Fe}$ were determined by using nitricperchloric acid digestion and atomic absorption spectroscopy. Total chlorophyll of leaf tissue were extracted and quantified by the dimethyl sulfoxide method of Hiscox and Israelstam (1979).

Soil samples were taken from each of the sites. The soils were dried, ground and analyzed for mineral composition using the Technicon Auto Analyzer and the Atomic Absorption Analyzer. Soil $\mathrm{pH}$, composition and type were determined on the soils from the different transect sites. Soil moisture was determined by taking soil samples in moisture sealed containers at the three locations at each site.

The data obtained from the site analyses were analyzed by statistical methods using the computer program, Statview II.

\section{HYPOTHESIS ONE: NONPATHOGENIC FACTORS ARE THE CAUSE OF UTAH JUNIPER DIE-OFF.}

After analyzing the data obtained last year from the Natural Bridges area, no strong correlation was found between soil elements and die-off.

The $\mathrm{pH}$ and the soil composition in the Needles area were similar in all of the transects. The element analysis of healthy, green diseased and diseased yellow leaves revealed that the concentration of iron, magnesium and calcium were significantly higher in the diseased yellow tissue. In contrast, the level of manganese was the lower in the diseased yellow tissue as compared to the healthy green tissue and diseased green leave tissue.

Particular attention was paid to the sodium content of the soil and to the foliar tissue of Utah juniper, since in an earlier study (Bunderson et al. 1986) there was a positive correlation between needle blight and high salinity.

\section{HYPOTHESIS TWO: PATHOGENIC AGENTS (VIRUSES MYCOPLASMA, BACTERIA, FUNGI, MISTLETOE, AND INSECTS) ARE THE CAUSE OF UTAH JUNIPER DIE-OFF.}

Few studies have been made on the diseases of Utah juniper. The juniper rusts (Peterson 1967) have been surveyed. The presence of diseases of Utah juniper on 17 sites were surveyed by Bunderson et al. (1986). The level of mistletoe infection on juniper on the south rim of the Grand Canyon was determined by Hreha and Weber (1979). The presence of bacteria, fungi, mistletoe and insects were evaluated as part of the disease survey on the transects at the different reference sites.

Isolation of organisms (bacteria, mycoplasma and fungi) were made using standard isolation procedures. Samples of twig and root tissue were fixed in $3.5 \%$ glutaraldehyde (in $0.1 \mathrm{M}$ phosphate buffer, $\mathrm{pH}$ 7.3) for $2 \mathrm{hrs,}$, washed overnight in fresh buffer and postfixed for $2 \mathrm{hrs}$ in $4 \%$ aqueous osmium tetroxide. They were dehydrated for $\mathbf{1 5} \mathrm{min}$ each in a acetone series of 30,50 , and $70 \%$ and then transferred to saturated uranyl acetate in $70 \%$ acetone and stained for $1 \mathrm{hr}$. After staining, the specimens were washed in $70 \%$ acetone for $3 \mathrm{hrs}$ dehydrated in 90 and $100 \%$ acetone, infiltrated overnight in eponacetone (1:1) mixture and embedded in epon. The thin sections were cut on a Porter-Blum ultramicrotome using a diamond knife and examined in a Phillips 400 electron microscope.

Last year the results from the evaluation of the soil and leaves from the Juniper transects in Natural Bridges National Monument did not reveal any clear cut pathogenic agent. Electron microscopy did reveal the presence of crystals in the chlorotic leaves. Since all of the trees evaluated in the transects were considered to be diseased, it is difficult to compare the data to a healthy tree. 
Plant tissue were prepared by a similar method to look for viruses using the electron microscope.

The needle blight of the trees was present in the Needles area in trees with and without twig cutters. In several of the transects, twig cutters (larvae of long horned beetles) were found to be an important component of the chlorotic appearance of the junipers.

The presence of insects borers were recorded during the reading of the transects. A few insects were collected. The trunks along the transects were observed for possible borers that could be causing damage to the junipers.

\section{HYPOTHESIS THREE: A COMBINATION OF DROUGHT HIGHER SALINITY AND TEMPERATURE STRESS ARE THE CAUSE OF UTAH JUNIPER DIE-OFF.}

The southwestern part of Utah has been experiencing a severe drought over the past several years. As drought occurs, salinity tends to move up to the upper layers of the soil. Since Utah juniper is salt sensitive, it is possible that these combinations could be contributing to the die-off problem. At the same time, endomycorrhiza and ectomycorrhiza have been reported to be present on Utah juniper (Reinsvold and Reeves 1986, Klopatek and Klopatek 1987). The mycorrhiza increases the water absorption and mineral uptake capacity of Utah juniper. If the mycorrhiza on the juniper roots are decreasing, it could result in decreased water and mineral uptake and this could be an important aspect in the die-off problem. VA mycorrhiza on roots from Utah juniper have previously been observed (Weber et al. unpublished data). Soil and fine roots from the Utah junipers growing at the different sites were collected and the amount of VA mycorrhiza is being determined using the methods of Schenck (1982).

\section{- RESULTS AND DISCUSSION}

The seven reference transects previously established in Natural Bridges National Monument were evaluated again to determine if any changes in the extent of juniper die-off had occurred in the past year with the increased moisture. The amount of die- off was lower in 1992 as compared to 1991 (Table 1). A completely healthy tree was not observed in any of the transects.

Hypothesis one: Simple correlations were made with tip dieback, leaf blight and senescence and the soil factors. High correlations between these factors were not observed in the Natural Bridges area. Similar correlations were made with the elements in the plant tissue, and no high $r^{2}$ values were obtained. In the Needles area, the element analysis of healthy, green diseased and diseased yellow leaves revealed that the concentration of iron, magnesium and calcium were significantly higher in the diseased yellow tissue as compared to healthy green tissue. In contrast the level of manganese was the lower in the diseased yellow tissue as compared to healthy green tissue and diseased green leave tissue.

Hypothesis two: No pathogens were isolated from the leaves. Twig cutters (larvae of long horn beetles) were found to be an important factor in the chlorotic appearance of the junipers in several of the transects in the needles area, but die-off symptoms were found on trees and branches not affected by the twig cutters. Electron microscopy analysis indicated considerable modification in the diseased cells and the presence of crystals. It is not known at this time if the crystals are made up of calcium oxalate or viruses.

Hypothesis three: No strong correlation between soil moisture, soil salinity and juniper die-off was observed. But as the drought has been reduced the amount of juniper die-off has also decreased (Table 1).

\section{$-\quad$ CONCLUSIONS}

After 18 months of study, information on the extent of the juniper die-off and the elements in the soil and in plant tissue has been obtained from two study areas. No causal agent of juniper die-off has been isolated at this time. The decrease in juniper die-off in relation to the decreased drought would give some support to hypothesis three as the cause of juniper die-off. 
Table 1. Comparison of disease ratings for junipers in the Natural Bridges National Monument for the years 1991 and 1992.

\begin{tabular}{|l|c|c|c|c|c|}
\hline \multicolumn{1}{|c|}{ Attribute } & 1991 & std. error & 1992 & std. error & Change \\
\hline $\begin{array}{l}\text { Needle blight } \\
\text { tree rating* }\end{array}$ & 1.45 & 0.26 & 0.83 & 0.23 & -0.62 \\
\hline $\begin{array}{l}\text { Senescence tree } \\
\text { rating* }\end{array}$ & 2.41 & 0.70 & 2.09 & 1.12 & -0.32 \\
\hline $\begin{array}{l}\text { Tip dieback } \\
\text { tree rating* }\end{array}$ & 0.98 & 0.18 & 0.86 & 0.26 & -0.12 \\
\hline $\begin{array}{l}\text { Rust Galls } \\
\text { no/tree }\end{array}$ & 1.01 & 0.82 & 0.22 & 0.30 & -0.80 \\
\hline $\begin{array}{l}\text { Fusiform Rust } \\
\text { tree rating* }\end{array}$ & 0.54 & 0.47 & 0.34 & 0.30 & -0.20 \\
\hline $\begin{array}{l}\text { Witches } \\
\text { Brooms Rust } \\
\text { tree rating* }\end{array}$ & 0.03 & 0.10 & 0.10 & 0.21 & 0.07 \\
\hline $\begin{array}{l}\text { Mistletoe } \\
\text { no/tree }\end{array}$ & 0.05 & 0.10 & 0.10 & 0.26 & 0.05 \\
\hline Insect Bores** & $* * 0.06$ & 0.10 & $* * 4.02$ & 0.10 & $* *$ \\
\hline $\begin{array}{l}\text { Insect "Pear" } \\
\text { Galls no/tree }\end{array}$ & 0.85 & 0.95 & 1.89 & 2.94 & 1.04 \\
\hline
\end{tabular}

* Tree rating signifies the fraction of the tree effected: 1) $0-20 \%$, 2) $21-40 \%$, 3) $41-60 \%$, 4) $61-80 \%$, 5) $81-100 \%$, 6) dead.

** In 1991 Insect Bores were measured as a tree rating, in 1992 individual insect bores were counted.

\section{$\checkmark \quad$ SUMMARY}

A comparison of the disease ratings from 1991 and 1992 from the juniper transects in Natural Bridges National Monument indicated that there was a reduction in the amount of needle blight in 1992. This may be a reflection of higher moisture conditions in the area during 1992. A comparison of healthy, green diseased and yellow diseased leaf tissue revealed a higher content of calcium, magnesium and iron in the yellow tissue. However in the case of manganese the yellow diseased tissue content was similar to healthy tissue. Twig cutters (larvae of long horned beetles) found in the Needles area of Canyonland to contribute significantly to the chlorotic branches. However, needle blight was also present in the absence of the twig cutters.

\section{$-\quad$ LITERATURE CITED}

Bunderson, E. E., D. J. Weber and D. L. Nelson. 1986. Diseases associated with Juniperus osteosperma and a model for predicting their occurrence with environmental site factors. Great Basin Naturalist 46:427-440.

Hreha, A. M. and D. J. Weber. 1979. A comparative distribution of two mistletoes: Arecuthobium divarcatum and Phoradendron juniperinum (South Rim, Grand Canyon National Park, Arizona) Southwestern Naturalist 24:625-636.

Hiscox, J. D. and G. G. Israelstam. 1979. A method for the extraction of chlorophyll from leaf tissue without maceration. Canadian Journal Botany 57:133-1334. 
Klopatec, C. C. and J. M. Klopatek. 1987. Mycorrhiza microbes and nutrient cycling processes in pinyon-juniper systems. pp. 360-362 In: Proceedings--pinyon-juniper conference, Reno, Nevada, 13-16 Jan 1986. USDA For. Ser. Gen. Tech. Rep. INT-215.

Peterson, R. S. 1967. Studies of juniper rusts in the West. Madrono 19:79-91.

Phillips, E. A. 1959. Methods of vegetation study. Holt Reinhart and Winston, Inc. New York. $107 \mathrm{pp}$.
Reinsvold, R. J. and F. Brent Reeves. 1986. the mycorrhiza of Juniperus osteosperma: identity of the vesicular-arbuscular mycorrhizal symbiont, and resynthesis of VA mycorrhiza. Mycologia 78:108-113.

Schneck, N. C. 1982. Methods and principles of mycorrhizal research. American Phytophathological Society. 244 pp. 